\title{
SONGS OF THE CANON: Song of Solomon and "Song of Myself"
}

EMMY STARK ZITTER

IN HIS CATALOGUE OF BIBLICAL ALLUSIONS in Whitman's poetry, Gay Wilson Allen found only one direct allusion to the Song of Solomon, in the story "Shirval" from The Half Breed and Other Stories. ${ }^{1}$ But Whitman's own great song, the "Song of Myself," reflects the influence of the Song of Solomon, echoing certain phrases, using similar stylistic techniques, and revealing some of the same thematic concerns as that difficult and ambiguous Biblical work.

The influence of the Bible on the poetry of Walt Whitman has long been noted. As early as 1866, W. D. O'Connor pointed to correspondences between Whitman's work and biblical literature, especially that of the Old Testament. ${ }^{2}$ More recently, such critics as R. W. French, Denise Askin, and Floyd Stovall discuss Whitman as a type of Old Testament prophet, "for the concerns of prophecy came to be central to Whitman's concept of poetry." 3 Allen, the most tireless of those critics who study the Bible as background to Whitman's work, has often discussed the analogous stylistic techniques of the Scriptures and the poems of Walt Whitman. He concludes that "no book is more conspicuous in Walt Whitman's 'long foreground' than the King James Bible."4

But if Whitman's works can be seen to reflect the influence of the Bible, both in style and content, they can also be studied as rebuttals of the wisdom of the Holy Books. Whitman himself conceived the notion of a "Great Construction of the New Bible," implicitly rejecting the old one. ${ }^{5}$ David Hiscoe finds suspect the insistence of early biographers on the importance of the Bible to Whitman's works, "given their desire to make him into the American Christ," and he sees in "Song of Myself" a mockery as well as an imitation of Paul's "thorn in the flesh."6 Marilyn Teichert discusses Whitman's audacious and nearly heretical indictment of nineteenth-century Christians, "the 'Pharisees' of his own time," and compares the reaction of Whitman's contemporaries to the shock of those who first heard and rejected the message of the Christian Bible. ${ }^{7}$

Whitman's poetry, then, both reflects and rejects conventions and ideas of the Scriptures. ${ }^{8}$ This dual nature in his work is especially pronounced in "Song of Myself," which shows, in Whitman's own words, "the greatest of faiths and the least of faiths" (1097). Such a contradiction certainly does not disturb Whitman:

Do I contradict myself?

Very well then I contradict myself,

(I am large, I contain multitudes.) (1324-1326) 
Nevertheless, one can try to reconcile these contradictions in Whitman's attitude toward the Bible, and a comparison of "Song of Myself" and The Song of Solomon is illuminating. Song of Solomon is perhaps the most ambiguous and least "scriptural" of the Scriptures. Consciously or unconsciously using it as a source for "Song of Myself," Whitman created a work which rejected some basic precepts of nineteenth-century Christianity while using the tone, style, and yes, the spirit of the Holy Books themselves.

In his catalogue of biblical allusions in Whitman's poems, Allen found only two general or inclusive biblical allusions in "Song of Myself," despite hundreds of such allusions throughout Whitman's works. ${ }^{10}$ The lack of specific allusion is not surprising, given the poem's avowed rejection of "second or third hand" knowledge (34). Basic to the philosophy of "Song of Myself" is the idea that man must look to himself and to his own experience, rather than to the words of his ancestors, in his quest for knowledge and truth. As Lewis Mumford has written, "such faith [as Whitman's] does not need external props and certitudes; it mocks at the testimony of bibles, for it is itself the source of such testimony." 11 Whitman rejects as inadequate the wisdom of the old religions, of all religions. He opens the poem by placing "creeds and schools in abeyance" (10), not denying that there is a truth to be found in religion, but refusing to believe that there is just one truth, one sect of religion whose words and practices can give the final answer to all our questions. Whitman presents a demanding test for ultimate truth, one which no conventional religion can ever hope to satisfy. "Only what proves itself to every man and woman is so," he says after rejecting the force of "logic and sermons," "only what nobody denies is so" (654-656). Thus, though Whitman listened to the voices of the ancient, exalted religions, he found them all lacking:

I heard what was said of the universe,

Heard it and heard it of several thousand years;

It was middling well as far as it goes-but is that all? (1023-1025)

He follows these challenging lines with a catalogue of those worshipped as gods through time, concluding in a quintessentially Yankee tone that he is "taking them all for what they are worth and not a cent more" (1033). Again, the point is not that there is no truth in these old ideas-after all, Whitman himself admits about his poem that "These are really the thoughts of all men in all ages and lands, they are not original with me" (355)-but rather that each person can and must arrive at his own truth in his own way, based on what he sees in himself and in the world around him. Whitman does not object to "special revelations," but he considers "a curl of smoke or a hair on the back of my hand just as curious as any revelation" (1039). He finds in the eyes of "Oxen that rattle the yoke and chain or halt in the leafy shade . . / . . more than all the print I have read in my life" (236).

Small wonder, then, that there is little overt biblical influence in this 
work; "Song of Myself" is a poem whose very essence is the rejection of truth based upon another's experience or revelation, the rejection of truth founded on the authority of another's words. And for all the power of his own "prophetic screams" (572), Whitman himself refuses to make his words into an authoritative source for others. He might well have been appalled at Mumford's designation of his poems as "sacred literature," for his is the philosophy of endless questioning that leads to new resolutions, new truths and newer questions. ${ }^{12} \mathrm{He}$ salutes his "Eleves," encourages them to "come forward" (974) and to question him, but ultimately demands that they reject his truth for one of their own creation: "He that by me spreads a wider breast than my own proves the width of my own, / He most honors my style who learns under it to destroy the teacher" (1234-1235). Whitman tells his students that he leaves them "no chair, no church, no philosophy" (1205), that his "barbaric yawp" (1333) is untranslatable, and that finally they must create their own expressions of truth.

Yet, despite the poem's pose of independence from authoritative sources, "Song of Myself" clearly shows the influence of Song of Solomon. Certainly both works share an occasionally confusing mingling of the dramatic and lyrical modes. The second chapter of Song of Solomon, for example, switches from the famous lyrical description beginning "I am the rose of Sharon," to the dramatic scene of the love-sick maiden asking for help, to the beloved's invitation to his love. ${ }^{13}$ Other such examples abound; indeed, the Song of Solomon has been variously interpreted as a collection of lyrical love poems, or as a pastoral drama. ${ }^{14}$ "Song of Myself" is filled with these mid-gear genre switches also. Whitman's admiring lyric about animals "So placid and selfcontain'd" (684) turns into the riding scene; even more dramatically, the stories in Sections 35 through 37 turn into the remarkable scene of Whitman's renewal, and then continue with his lyric celebration of the "friendly and flowing savage" (976). The tension here is provided not only by shifts in genre, but by equally dramatic changes in the poetic mood. Now the poet is the objective storyteller; now he is the shamed and beaten beggar; now he is the strong and restored teacher of athletes. There is in Song of Solomon an analogous alternation between moods of exultation and despair-for example, the celebration of love and the mourning for its loss in the third chapter. This portion of Song of Solomon is divided between the pathos of the search for the lost love and the lyrics of the joyous arrival of King Solomon's wedding litter. The contrast between the moods of the two scenes is more striking for the similarity in their imagery. In the first episode the dark is full of nightmares and the watchmen are of no use, while in the latter song sixty heroes ward off the terrors of the night.

Such general stylistic similarities between the Song of Solomon and "Song of Myself," however, are hardly enough to prove a link between the two poems. More telling are the direct echoes of the Song of Solomon that can be heard in Whitman's poem. Both works begin with fragrance: Song of Solomon 
opens with the "savor" of the lover, which is like "good ointments" (1:3), while "Song of Myself" presents "houses and rooms [that] are full of perfumes" (14). A more general echo of Song of Solomon is the vision of women as "my sisters and lovers" (94), a formula common in the biblical work. ${ }^{15}$ Whitman's poem includes other expressions and lines that are not direct quotations from or allusions to the Song of Solomon, but that ring with the same tone of mythic passion. One such verse is the culmination of Whitman's impassioned love song to the earth:

\author{
Smile O voluptuous cool-breath'd earth! \\ Earth of the slumbering and liquid trees! \\ Earth of departed sunset -earth of the mountains misty-topt! \\ Earth of the vitreous pour of the full moon just tinged with blue! \\ Earth of shine and dark mottling the tide of the river! \\ Earth of the limpid gray of clouds brighter and clearer for my sake! \\ Far-swooping elbow'd earth-rich apple-blossom'd earth! \\ Smile, for your lover comes. (438-445)
}

The final line of the song distinctly reflects the tone of comforting passion that pervades the Song of Solomon. This style is particularly marked in the famous biblical celebration of nature and love in the second chapter of Song of Solomon. Here the beloved calls to his lover to come with him to greet the spring:

Rise up, my love, my fair one, and come away.

For, lo, the winter is past,

The rain is over and gone;

The flowers appear on the earth;

The time of the singing of birds is come,

And the voice of the turtle is heard in our land;

The fig tree putteth forth her green figs,

And the vines with the tender grape give a good smell.

Arise, my love, my fair one, and come away. (3:10-13)

These lyrics share a stunning sensuousness in their descriptions of the land, a tone that is emphasized by the contrasting frame of the opening and closing lines with their simple but arresting commands of passion.

The Song of Solomon is unique in the biblical canon because it lacks an overt national or religious theme. Because of its sensuous nature, the poem's acceptance into the canon was based on an allegorical interpretation, expounded first by Hebrew and later by Christian scholars. ${ }^{16}$ Two of the most interesting echoes of the Song of Solomon in Whitman's poem reflect some knowledge of the poem as allegory. Section 45 of "Song of Myself" is a lyric of affirmation, a celebration of "limitless space" and "limitless time" in a universe where "There is no stoppage and never can be stoppage" (1190-1196). This section ends on a note of faith and renewal: 
My rendezvous is appointed, it is certain,

The Lord will be there and wait till I come on perfect terms,

The great Camerado, the lover true for whom I pine will be there. (1197-1200)

The melding of the languages of love and of religious experience-the picture of God as a lover for whom one pines - reflects an allegorical interpretation of Song of Solomon. Ironically, these lines, with their overt reference to God, seem more biblical in their way than the Song of Solomon itself; after all, the King James translation of the poem does not include any overt mention of God at all. ${ }^{17}$ Another example of Whitman's play with the allegorical ideas of the Song of Solomon occurs early in the poem and is explicit only in the 1855 edition. In Section 3, where he sings about the "procreant urge of the world" (44), he writes of a God who "comes a loving bedfellow and sleeps at my side all night and close on the peep of the day" (1855 version). Again there is the explicit, and here quite sensuous, use of the lover-image to describe Whitman's relationship to his God, in keeping with the interpretation of Song of Solomon as an allegory of love between God and man.

Because Whitman chose to change his allusion from God as a "loving bedfellow" to a less explicit description of the "hugging and loving bed-fellow," and because of his earlier sarcastic remark about those who are "proud to get at the meaning of poems" (32), one might be tempted to argue that Whitman was consciously examining and finally rejecting the allegorical interpretation of the Song of Solomon. There is, however, simply not enough specific proof to back up such a contention; in fact, Allen admits we cannot prove even a conscious imitation of the Bible in Whitman's works. ${ }^{18}$ But solving the problem of Whitman's conscious or unconscious echoes of Song of Solomon in "Song of Myself" is less important than illuminating the thematic links between the two works.

Stovall describes "Song of Myself" as a "trilogy" of three dominant themes, "Democracy, Love, and Religion"; in the Song of Solomon Whitman has found a touchstone for a discussion of the latter two ideas. ${ }^{19}$ Whitman's use of the allegorical image of a lover as God does not mean that he, like the theologians of his time, rejected the literal celebration of love in the Song of Solomon. "Song of Myself" is a rejoicing in frank sensuality, such as the story in Section 11, the short and poignant description of the lonesome woman of twenty-eight years who watches the men bathing by the sea. "She hides handsome and richly drest aft the blinds of the window" (203), says Whitman. This picture of a woman's shy longing turns inside-out the famous description from Song of Solomon of the young man as he sings to his lover an invitation to love:

Behold, he standeth behind our wall,

$\mathrm{He}$ looketh forth at the windows,

Showing himself through the lattice.

My beloved spake, and said unto me,

Rise up, my love, my fair one, and come away. (2:9-10) 
A comparison of the repressed young woman of Whitman's poem and the inviting, sensuous man of the Bible underscores Whitman's celebration of open physical love and, for that matter, emphasizes the physical focus in a literal interpretation of the Song of Solomon. Teichert finds a "Gospel of Sexuality" in Whitman's Children of Adam poems, and Whitman may be using the most overtly sexual of the Scriptures to convey the same kind of message here ${ }^{20} \mathrm{In}$ his Preface to the 1876 edition, Whitman stated that his purpose in Leaves of Grass was "to express, above all artificial regulation and aid, the eternal Bodily Character of One's-Self," and he adds parenthetically that:

... the brawn of Leaves of Grass is, I think, thoroughly spiritualized everywhere, for the final estimate, but, from the very subjects, the direct effect is a sense of the Life, as it should be, of flesh and blood, and physical urge, and animalism. ${ }^{21}$

Whitman states his case more succinctly in Section 48 of "Song of Myself": "I have said that the soul is not more than the body, and I have said that the body is not more than the soul" (1269-1270). This is a thematic center of "Song of Myself"; it reflects the synthesis of the physical and spiritual that a reading of the most sensual work of the Judeo-Christian tradition can express so well. Classical Christian theology has created a dichotomy of loves, dividing love into eros, which is carnal, and agape or caritas, which is spiritual love. Robert Gordis points out that the classical Hebrew expression for love, $a h a b a$, does not reflect such a division, but rather can be used in spiritual or physical descriptions. ${ }^{22}$ There is no evidence that Whitman knew the Judaic conception of love, but consciously or unconsciously, he tries in "Song of Myself" to return to this original, undivided view of love as a thing of the body as well as of the soul. What better text to use as a source than Song of Solomon, a work whose literal meaning celebrates the physical, but one whose inclusion into the biblical canon hints at the spiritual possibilities of just this physical side. Whitman rejects physical love as only an allegorical construct because it creates a hierarchy where the allegorical meaning is more truthful than the literal. The soul becomes greater than the body, contrary to the message of Whitman's poem.

Teichert discusses the audacity of Whitman's heretical celebration of physical love in Children of Adam, but a study of the Song of Solomon as a source for "Song of Myself" shows that here is no real heresy, but rather a return to a more authentic scriptural view of love. The heresy is aimed only at those who refuse to acknowledge the literal celebration of physical love in Song of Solomon, those who "lie awake in the dark and weep for their sins," those whose sense of guilt or "duty to God" (686-687) has led them to demean their bodies as a perverted means of exalting their souls. "Song of Myself," with its picture of a woman's repressed sexuality in Section 11, looks backward to an earlier, freer day, when the beloved peered through the lattice to celebrate the beauty of physical love-not, like Whitman's woman, to hide from it. 
Besides Whitman's identification with the prophets of the Old Testament, there is another biblical character whose image is reflected in the persona of "Song of Myself." Leader of his people, sage, builder of great houses, rider of horses, lover of women, writer of songs - in the mythic character of King Solomon Whitman may well have found a foundation for the "august" (409) and lusty singer of the "Song of Myself." The poem is a celebration of Democracy and a repudiation of authority, but part of its sensibility is based on the words of the most famous monarch pictured in the Bible, itself the most authoritative work of Whitman's experience. Many of the ideas and images in "Song of Myself" are based on the words of a king whose name is given to a book of love songs revered as holy by a religion whose adherents had, in Whitman's view, perverted the very meaning of love. Perhaps Whitman was aware of these ironies; if he was, he reveled in them, more evidence of the contradictions in himself, in his world, and especially in his poetic works.

\section{University of Rochester}

\section{NOTES}

1 Gay Wilson Allen, "Biblical Echoes in Whitman's Works," American Literature, 26 (1934), 307.

2 W. D. O'Connor, “Current Literature: Walt Whitman," New York Times, 2 December 1866, Sec. 2, p. 1. O'Connor saw similarities "to the poetic diction of the Hebraic muse," but he finally found the similarities "more apparent than real," for Whitman's was the rhythm of contemporary America.

3 Roberts W. French, "The Voice of the Prophet: Collapse and Regeneration in 'Song of Myself," The English Record, 32 (Winter 1981), 2. See also: Denise T. Askin, "Whitman and the Law: A Prophetic Parallel,"Walt Whitman Review, 27 (1981), 125-132; and "Introduction" to Walt Whitman, Representative Selections, ed. Floyd Stovall (New York: American Book Co., 1939), xi-lii. Askin finds Whitman reflecting the attitude of Biblical prophets, interpreted in the Christian tradition, to the law. She sees in the prophecies a three-fold message: "the diatribe against Israel's breaking of the covenant, the attack on the priestly ritualistic distortion of the law, and the annunciation of a new law rooted in love and individualism." (p. 128).

4 Gay Wilson Allen, A Reader's Guide to Walt Whitman (New York: Farrar, Straus \& Giroux, 1970), 24.

5 Quoted by David W. Hiscoe, "St. Paul and Whitman's Thorn'd Thumb," Walt Whitman Review, 27 (1981), 82.

6 Hiscoe, 83.

7 Marilyn Teichert, "Children of Adam: Whitman's Gospel of Sexuality," Walt Whitman Review, 28 (1982), 26. An interesting example of unfavorable contemporary reception of Whitman's works is the brief editorial introduction to the favorable review by O'Connor (see note 2). The New York Times found O'Connor's praise of Whitman excessive: "Nor can we fail to note that while he sometimes thus soars aloft in the very highest regions of thought and song, Walt Whitman often also wallows exultingly in unredeemed and irredeemable indecency and filth." 
8 Laurence I. Berkove, "Biblical Influences on Whitman's Concept of Creatorhood," Emerson Society Quarterly, 47, 2 (1967), 34, says that "to Whitman, the Bible represented a model of sublimity and a rival philosophy. The one he tried to match; the other to supplant."

9 Walt Whitman, Leaves of Grass, Norton Critical Edition, ed. Sculley Bradley and Harold W. Blodgett (New York: W. W. Norton Co., 1973). All quotations from "Song of Myself" are from this edition, with line numbers indicated parenthetically in the text.

10 Allen, "Biblical Echoes," 310.

11 Lewis Mumford, "High Noon," in Leaves of Grass, Norton Critical Edition, 854.

12 Mumford, 854.

13 All references to the Song of Solomon are from the Westminster Study Edition of The Holy Bible, Containing the Old and New Testaments In the Authorized (King Fames) Version (Philadelphia: Westminster Press, 1948), 910-916.

14 For a concise review of various Jewish and Christian interpretations of Song of Solomon, see Robert Gordis, The Song of Solomon and Lamentations: A Study, Modern Translation, and Commentary (New York: Ktav Publishers, 1974), 1-18.

15 See, for example, Song of Solomon 4:9-12 and 5:1.

16 Gordis, 2-4.

17 Judaic editions include one overt mention of God, as they translate the word shalhevetya, 8:6, as "a flame of God." The King James version translates the expression as "a most vehement flame." Even the Judaic versions, however, use God's name only descriptively here.

18 Gay Wilson Allen, "Biblical Analogues for Walt Whitman's Prosody," Revue anglo-américaine, 10 (1933), 491.

19 Stovall, xxv.

29 Teichert, 25.

21 Leaves of Grass, Norton Critical Edition, 750-752.

22 Foreword to Gordis, $\mathbf{x}$. 